\title{
Investment Strategy of Captive Insurers - Are Risk Managers Becoming Investment Managers?
}

\author{
by M. Moshe Porat and Anthony F. Gasich *
}

\begin{abstract}
Captive insurers have been largely perceived as risk financing vehicles, that among other things, generate a superior investment performance. That perception was advanced by promoters injecting tax advantages and a free investment atmosphere as key factors. Previous research has shown that captives, by and large, are rather conservative in terms of their underwriting exposure and insurance leverage posture. These findings invited a supposition that such conservatism would afford more risk taking in investments. While risk managers have been involved in operating captives for the last two decades, unanswered is the question of their involvement, if any, in investment decisions or investment management. Very little has been written on this subject and practically nothing on an empirical basis. A questionnaire approach was used to gather the data with which to answer the question of what is the risk manager's role in captive investment strategy and other related issues. A model of captive's investment strategy is presented in which the outputs - instruments, maturities and currencies - were a function of investment policy issues such as who sets the policy, the investment policy criteria; and investment management issues such as who manages the portfolio, who selects the manager, and manager's selection criteria. All inputs boiled down to four main components; "risk" versus "return" for investment criteria and "insiders" versus "outsiders" for the personnel who select or manage the investment portfolio. The key finding of the study was a general reaffirmation of captives' conservatism which apparently spilled over into their investments operations. Captives have pursued a generally short term investment strategy using primarily short term instruments mostly for short maturities. Equities and mutual funds were almost inexistant. Captives investment strategy is largely dominated by minimizing "risk" concerns rather than by maximizing issues of "return". It also becomes evident that the most influential individuals in setting guidelines and/or managing portfolio are inside personnel. Risk managers appear to be quite influential in setting policy or selecting the investment manager but, the least likely candidates for actual management of the portfolio. Investment performance of captives, in the year of the survey, was compatible with the overall investment performance of the U.S. property and casualty industry. However it was largely below investment performance yardsticks applied to investment return in other industries.
\end{abstract}

\footnotetext{
* M. Moshe Porat, Ph.D., CPCU, is an Associate Professor and Chairman of the Department of Risk Management and Insurance at Temple University's School of Business and Management, Philadelphia, Pennsylvania. Anthony F. Gasich, CLU is a doctoral candidate in Risk Management and Insurance at Temple University and also with the American Insurance Institute.

The authors wish to acknowledge the valuable contribution to the study by Mr. Thomas E. Rattman, C.F.A., Senior Vice President, CIGNA International Investment Advisors Ltd.

This study was supported in part by a grant-in-aid of research of Temple University.
} 


\section{Introduction}

In a perfect market place investment income earned by insurers would be reflected appropriately in premium rates. Thus the fact that captives insurers have access to investment income should not have been an advantage over regular insurers. However, market imperfections do exist and insurers do not necessarily pass that income down to their insureds. Also most captives have conducted their investment activities offshore in a presumably more free investment atmosphere, and investment income generated from underwriting risks located offshore had enjoyed a tax advantage (deferral up to 1987) over other income sources.

For these reasons captives have been perceived and promoted as vehicles for generating better investment income even in an atmosphere of diminishing tax and other operational advantages of offshore captives. Indeed the captive movement has generated substantial amounts of investable funds. In Bermuda alone, the home of more than two thirds of offshore captives, the amount of investable funds exceeded 20 billion dollars in 1986.

Therefore, many have questioned whether or not captives employ any unique investment strategy or enjoy better investment performance over regular insurers. This question is particularly interesting in view of captives rather conservative underwriting exposure and insurance leverage ratios. Moreover, in light of the important role risk managers have played in operating and decision making of captive insurers one would be curious as to their actual role in handling investment for their captives, an area that traditionally has been perceived as the domain of parent financial officers.

The objective of this study was threefold:

First, to compare investment patterns of offshore captive insurers with the regular U.S. property and casualty industry. This involved collecting data that to best of our knowledge have not been available or collected as yet by anyone. Second, to establish a concept of an investment strategy pursued by captives, if any, and analyze the imputs that enter into that strategy. Subsequently to explain any variations in investment strategies due to differences among captives in terms of their financial characteristics (such as size, exposure and leverage), in terms of their structural characteristics (such as parent industry, ownership and organizational forms) and in terms of their operational characteristics (such as class of business written, age of captive, type of writing method and type of management). Third, to assess the role of the risk manager, if any, in forming an investment strategy for the captive as well as in the actual execution of the investment strategy.

\section{Research methodology, data sources and presentation}

Very little published data are available on financial operations of offshore captives and even less so on their investment activities and performance. Our continuing contacts with risk managers who operate captives made the questionnaire approach a feasible source of data. A pilot study was conducted among some investment practitioners, captive managers and risk managers, for the purpose of formulating questions, phrasing category answers and testing the validity of a provisional questionnaire. A final questionnaire was developed and sent to a sample of about four hundred offshore captives, mostly domiciled in Bermu- 
da. About 300 questionnaires reached their appropriate destinations. Some 120 responded of whom 80 returned completed questionnaires (see sample of the questionnaire on pages 394 to 396 ). The 80 respondents combined generated some U.S. $\$ 2.8$ billion of investable funds in 1985. This amount constituted about $20 \%$ of all Bermuda active captives' investable funds for that year. The respondents constituted a relatively substantial sample of the actual population. However, as compared to Bermuda's actual population of captives the sample of respondents for that year was somewhat underrepresented in the category of "small" captives (up to $\$ 2.5$ million in assets); the sample was very well represented in the "medium" size category of captives (\$2.5 to \$10 million in assets) and somewhat overrepresented in the "large" ( $\$ 10$ to $\$ 50$ million in assets) and the "extra-large" (over $\$ 50$ million in assets) categories of captives. To make the sample more compatible in representing the actual population three cases of outlier observations were removed. This correction made the sample mean, median and variance much more compatible with the actual Bermuda captive population. Basic hypotheses were set prior to the structuring of the questionnaire concentrating on such key aspects as, investment instruments, maturities, currencies, criteria for investments, investment managers and other key personnel who are influential in the investment decision. The data involve offshore captives only, most of whom are domiciled in Bermuda. Basic statistical methods for identifying relationships and groupings for explanatory and predicting purposes were employed. It includes hypotheses testing, multiple regression, factorial analysis and scaling techniques (see endnote references for more technical explanations of the particular methods). The research report, key findings and conclusions are presented in the following order:

- Firstly, a comparison of the investment patterns of offshore captives with the investment patterns of U.S. property and casualty insurance industry.

- Secondly, the concept of an investment strategy of captive insurers and a hierarchy of the inputs in such a strategy, including the role of risk managers.

- Thirdly, a summary of the principal findings, conclusions and evaluations followed by a summary of the survey results, a profile of the respondents and a copy of the questionnaire.

\section{Investment patterns comparison}

\subsection{Offshore captives vs. U.S. property/casualty companies}

Formation rates of captive insurers for the last two decades have shown a strong positive correlation with the cycles of the property and casualty industry as expressed in the industry's operating income as a percentage of earned premium. ${ }^{1}$ Despite the ups and downs in formation rates of new captives the movement has experienced a continued real (discounted for inflation) growth in assets and net worth.

The Bermuda market which constitutes about two thirds of all offshore captives worldwide has experienced a growth rate of about 2 billion dollars annually in assets totalling some $\$ 31$ billion in 1986 of which real captives (excluding insurance related offshore entities) generated more than $\$ 20$ billion. $^{2}$ 
These large amounts of assets and net worth have made the captive movement an attractive market resource for investment funds. The offshore captive movement generates assets which amount to about 10 percent of the entire U.S. property and liability market, thus making the captive market one of the world's ten largest insurance markets and therefore very important investments market as well. Most investment and financial houses worldwide have established presence in captive markets in the last decade competing quite fiercely on captives investable funds. ${ }^{3}$

A general comparison of the investment allocations between captives (our survey respondents) and the U.S. P/C industry based on the 1985 financial year is summarized in Graph 1. The most striking finding in this comparison is the relative heavy emphasis of captives on short term investment instruments and their very modest investment in equities as compared to the U.S. P/C industry. Captives use primarily money market (short term) securities, bonds and loans to affiliates. The insurance industry allocates a greater proportion of its investments to bonds and by far less to short term instruments. Although investment in affiliates is the third largest investment allocation in captives still less than $16 \%$ of all captives invest in parent and affiliates which is contrary to what we might have expected (Table 1).

Graph 1

Investment allocations

BERMUDA CAPTIVES

$\begin{array}{ll}\text { Mortgages } & - \\ \text { Demand Accounts } & 2 \% \\ \text { Stocks } & 1 \% \\ \text { Other } & 1 \%\end{array}$

U.S. PROPERTY/CASUALTY CO'S Prelerred Slocks $3 \%$ Mortgages $1 \%$ Demand Accounts $2 \%$ Olher
$2 \%$
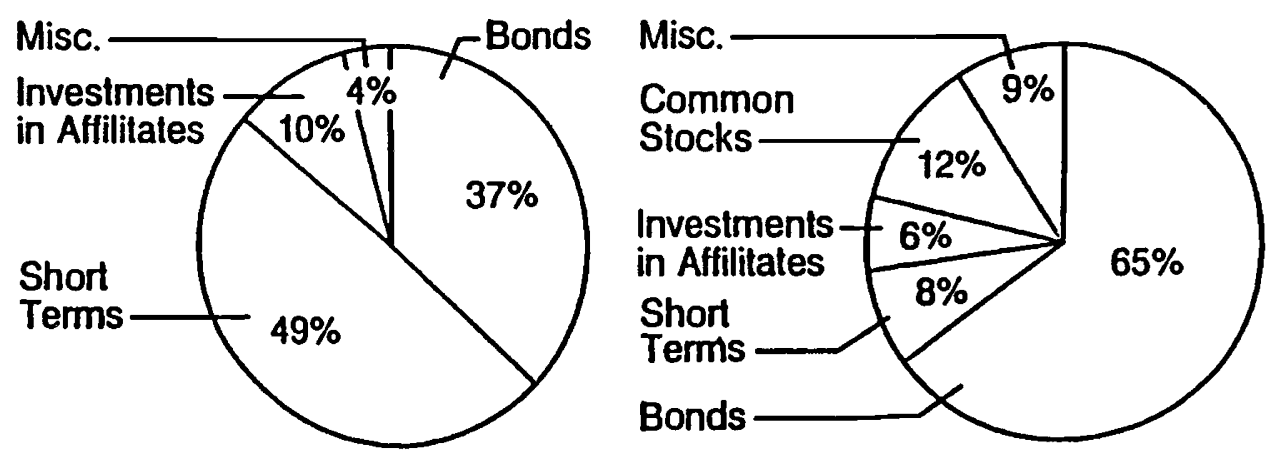

Clearly stocks which have played an important role in the portfolio of U.S. insurers are rather insignificant and rare among offshore captives. Less than 1 percent of all investable funds of captives were allocated to stocks and slightly more than $5 \%$ of all respondents used any equities at all (Table 1). 
Table 1

\section{Investment strategy outputs}

\section{1. - Investment instruments usage}

\begin{tabular}{lrrrrrr}
\hline lnstrument & $\begin{array}{r}\text { Respondents } \\
\text { Using }\end{array}$ & Rank & $\begin{array}{r}\text { Mean Usage } \\
\text { in Portfolio }\end{array}$ & Rank & $\begin{array}{r}\text { Mean Usage } \\
\text { Weighted* }\end{array}$ & Rank \\
\hline Demand Deposits & $53.2 \%$ & 2 & $5.6 \%$ & 6 & $3.7 \%$ & 6 \\
Time Deposits & $72.2 \%$ & 1 & $36.1 \%$ & 1 & $26.8 \%$ & 2 \\
Floating Rate Inst. & $34.2 \%$ & 4 & $8.8 \%$ & 4 & $12.7 \%$ & 3 \\
Short Terms (T-Bills, etc.) & $31.6 \%$ & 5 & $17.1 \%$ & 3 & $7.2 \%$ & 5 \\
Bonds & $53.2 \%$ & 3 & $28.1 \%$ & 2 & $37.7 \%$ & 1 \\
Equities & $5.1 \%$ & 7 & $1.4 \%$ & 7 & $0.8 \%$ & 7 \\
Mutual Funds & $1.3 \%$ & 8 & $1.0 \%$ & 8 & $0.4 \%$ & 8 \\
Loans to Parents & $15.9 \%$ & 6 & $6.3 \%$ & 5 & $10.5 \%$ & 4 \\
Mortgages & $1.3 \%$ & 9 & $0.4 \%$ & 9 & $0.2 \%$ & 9 \\
\hline
\end{tabular}

\section{2. - Investment instruments maturity dates}

\begin{tabular}{lrrrrrr}
\hline Maturity & $\begin{array}{r}\text { Respondent } \\
\text { Using }\end{array}$ & Rank & $\begin{array}{r}\text { Mean Usage } \\
\text { in Portfolio }\end{array}$ & Rank & $\begin{array}{r}\text { Mean Usage } \\
\text { Weighted* }\end{array}$ & Rank \\
\hline One month or less & $72.2 \%$ & 1 & $20.9 \%$ & 1 & $14.4 \%$ & 4 \\
$1-3$ months & $44.3 \%$ & 3 & $17.7 \%$ & 2 & $14.0 \%$ & 5 \\
3-6 months & $36.7 \%$ & 5 & $16.6 \%$ & 3 & $15.5 \%$ & 3 \\
6-12 months & $36.7 \%$ & 5 & $11.0 \%$ & 5 & $13.1 \%$ & 6 \\
1-2 years & $30.4 \%$ & 7 & $4.7 \%$ & 7 & $4.6 \%$ & 7 \\
2-5 years & $50.6 \%$ & 2 & $15.8 \%$ & 4 & $19.7 \%$ & 1 \\
5-10 years & $40.5 \%$ & 4 & $9.3 \%$ & 6 & $16.9 \%$ & 2 \\
10+ years & $8.9 \%$ & 8 & $1.3 \%$ & 9 & $0.8 \%$ & 9 \\
Indefinite & $6.3 \%$ & 9 & $2.5 \%$ & 8 & $1.2 \%$ & 8 \\
\hline
\end{tabular}

\section{3. - Mix of currencies}

\begin{tabular}{lrr}
\hline Currency & Weighted Usage* & Rank \\
\hline U.S. Dollar & $93.8 \%$ & 1 \\
Pound Sterling & $6.6 \%$ & 2 \\
Bermuda Dollar & $1.3 \%$ & 3 \\
Deutsche Mark & $0.7 \%$ & 4 \\
Japanese Yen & $0.5 \%$ & 5 \\
Canadian Dollar & $0.3 \%$ & 6 \\
Australian Dollar & $0.2 \%$ & 7 \\
French Franc & $0.2 \%$ & 8 \\
New Zealand & - & 9 \\
Dutch Florin & - & 10 \\
Others & $0.2 \%$ & 11 \\
\hline
\end{tabular}

* Weighted by the amount of investable funds in each instrument. 
Some other important observations may help to explain the sharp differences between captives and the U.S. P/C industry. Investable funds comprise $80 \%-95 \%$ of the average captive's total assets. For the U.S. P/C industry investable funds comprised only $70-75 \%$ of total assets. Although some captives have become very large - even the median captive in our sample had as much as $\$ 15$ million in assets, or $\$ 12$ million in investable funds - still most captives are relatively small as compared to most U.S. P/C insurers and relatively younger in age; the median age of our sample of captives was 8 years. Captives have also a rather conservative posture when it comes to their underwriting exposure ratio (net premium/net worth); a mean value of 1.55 compared to a 2.43 for non-captives (in Bermuda) and about 2.0 for the U.S. P/C industry. In terms of insurance financial leverage (reserves/ net worth) the captives mean value was 3.28 compared to 9.95 for non-captive insurers in Bermuda. It is also evident that most captives use their inhouse personnel and/or parent companies personnel in setting investment objectives rather than outside or unaffiliated personnel.

In conclusion the rather conservative posture both in underwriting exposure and insurance leverage that most captives have displayed, manifested itself also into their investment portfolio allocations. Furthermore the relatively modest size of most captives (about $30 \%$ of all captives have less than $\$ 2.5$ million in investable funds and two thirds of them have less than $\$ 10$ million (as based on 1985 financial information of all Bermuda captives) may not justify, according to some investment experts, maintaining inhouse an individual fully devoted to investments, which may express itself in a more naive and cautious strategy of preferring rather short term instruments and almost complete absence of equities. ${ }^{4}$

However, captives who should be probably familiar with parent loss exposures, better than anyone else, should at least theoretically have a larger tolerance for investment risk in view of their little tolerance of insurance/underwriting risks. It has also been known that larger investments returns have been associated with longer maturities rather than shorter ones. It appears, therefore, that captives actually behave almost contrary to what one might have prescribed or what many promoters have often suggested about the possible advantages of captives in the investment area. Our explanation to that phenomena is that insurance and underwriting conservatism among captives has spilled over to other risk taking primarily when the same personnel influence or execute those decisions. Most captives who are relatively inexperienced even in underwriting and insurance company management, and needless to say investments, are apparently satisfied with "acceptable" returns rather than seeking to maximize returns. Inexperience leads to short term orientation which translates to short term investments. This is commensurate with risk aversion in underwriting which many captives have displayed too. This conclusion applies to the majority of offshore captives. We are all aware, however, of some captives (even large ones) that went bankrupt, were liquidated, merged or became dormant because of aggressive and imprudent underwriting (primarily in writing third party business) and generally because they were poorly managed. ${ }^{5}$ 


\section{Investment strategy of captives and the role of risk managers in captives' investments}

The general hypothesis in our search for an investment strategy for captive insurers is that an investment strategy is a set of outputs namely actions/decisions generated from inputs concerning policy and management of investments.

Graph 2 is a general scheme of captives' investment strategy, inputs and outputs. The output of captives' investment strategy are actions regarding mix of instruments, maturities and currencies. The inputs that determine the strategy outputs can be generally grouped into what we connote as "policy inputs and management inputs". In policy inputs we refer to inputs regarding who sets the investment policy and the investment criteria used in setting the policy. In management inputs we refer to the actual managers of captives' investment portfolios, the selection process of the managers and the criteria for their selection. It is the combination of the policy and management inputs, which in turn may be influenced by other characteristics of captives, that set the strategy outputs namely mix of instruments, maturities and currencies.

Statistical data analysis techniques such as Factor Analysis helped us to reduce the great variety of policy and management inputs generated from the questionnaire into principal factors or components that explained best various groupings of individual inputs. ${ }^{6}$ Clearly the key factors among both policy and management inputs were clustered into two dichotomies: "insiders" versus "outsiders", in terms of principal components identifying the individuals who set policy, manage or select the manager of captives' investments; and "risk" versus "return", in terms of the principal criteria components for both setting investment policy and selection of managers.

Furthermore we have recognized that captives' investment strategy outputs directly, or indirectly via policy or management inputs, can be affected by the characteristics that distinguish one captive from another. In other words we introduced into the strategy model variables that represented captives operational, structural and financial characteristics, and tested impact on the ultimate investment strategy.

In sum our model of captives' investment strategy can be expressed (in a non mathematical way) as:

$\begin{aligned} \text { Investment Strategy } & =\text { A combination of: } \\ & {\left[\begin{array}{l}\text { Investment Policy Inputs } \\ \text { Investment Management Inputs } \\ \text { Captives Operational Characteristics } \\ \text { Captives Structural Characteristics } \\ \text { Captives Financial Characteristics }\end{array}\right] \quad=\text { A mix of: } }\end{aligned}$

The following discussion reviews the key empirical findings associated with the investment strategy model. Table 1 tabulates the findings regarding strategy outputs: Instruments, Maturities and Currencies.

Instrument mix. Time deposits (Bank time deposits, C.D.'s, etc.) have been the most widely used instrument (more than $72 \%$ of all captives). Demand accounts and Bonds fol- 


\section{Graph 2}

Investment strategy inputs

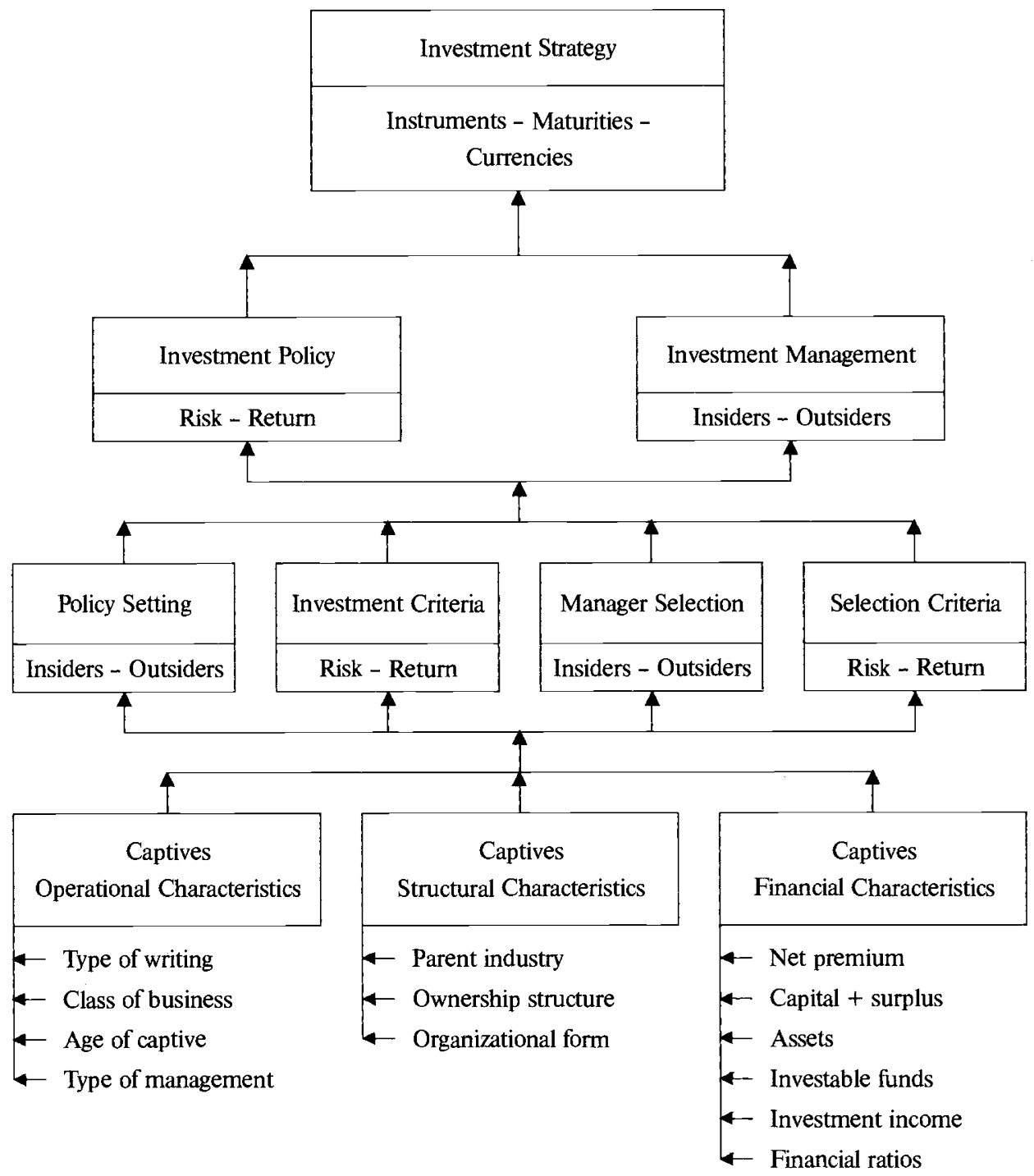


lowed by more than $53 \%$ usage each. To account for the varying degree of usage of each instrument by each respondent, a composite ranking based on the coefficient of variation (namely the standard variation divided by the mean) was used. This resulted in a usage index in which the time deposit instrument still ranked highest, followed by Bonds and other short term instruments such as commercial paper, Treasury bills etc. To account for the relative size of funds invested in each instrument by all captives in the sample, a weighted mean was computed. Bonds were ranked highest reflecting the relative large amounts invested in bonds. Further statistical testing ${ }^{7}$ for significant dependence between captive characteristic variables and instrument mix revealed that shorter term instruments, such as bank deposits, demand accounts etc., tended to be used more often by group captives and by captives who write primarily property lines. Bonds and equities tended to be used more intensely by older captives than by younger ones. This result could have been expected since older captives (having more experience) and those who wrote primarily liability lines (longer tails) would tend to invest in longer maturities, and vice versa.

Maturities mix. The most frequent maturity used by captives was "less than one month" followed by " $2-5$ years" and " $1-3$ months". Least frequent were the very long maturities, ten years and more. When adjusted for individual portfolio variability and weighted for size of investable funds, the most used maturity was the "2-5 years". This highlights the fact that for some captives (particularly older ones with experience) the medium term maturity is an important part of the investment strategy. Relatively large amounts of funds, among our respondents, were invested for this time frame. Nevertheless, still some $57 \%$ of all investable funds were invested for periods with maturities within one year. Close to $25 \%$ of the investable funds were invested for maturities between 1 and 5 years and the rest from 5 to 10 years. Only $2 \%$ of the funds were invested for periods longer than 10 years. Further statistical testing revealed that short term maturities, up to one year, were more often used by pure captives who were also small in size and by captives writing mostly property lines. Longer term maturities, 2-5 years and 5-10, were more often identified with larger captives and those writing primarily liability lines. Very large captives however used quite evenly short as well as long maturities. These results further highlight the statistically significant association between size, age, type of writing business and the preference of maturity mix. Clearly insurance needs and experience as may be reflected in size and age dictate maturity a great deal.

Currency Mix. It became quite apparent that the overwhelming majority of captives used solely the U.S. dollar currency. A few, less than $10 \%$ of the respondents have utilized other currencies primarily German Mark and British Pound for the purpose of either matching liabilities or speculate on future currency trends. $94 \%$ of all investable funds generated by the sample respondents were denominated in U.S. dollars. Thus, clearly currency mix was not a statistically significant variable in the investment strategy of most captives.

In conclusion the investment strategy output for captive insurers is practically composed of two variables: instrument mix and maturities mix. A more indepth analysis for statistical association between the two variables reveals a rather strong statistical correlation between the two as might have been expected. In other words those captives who chose instruments that are by the very nature of short term such as demand accounts, time deposits, treasury bills, etc. tended to invest for shorter maturity dates and vice versa. ${ }^{8}$ 


\subsection{Investment policy inputs}

Graph 3 details the elements of investment policy inputs. Investment policy makers and investment criteria are the key variables in an investment policy. To ascertain these we asked the respondents to rank individuals and investment criteria on a scale of 1 to 5 , where "l" indicated highest importance and " 5 " indicated no importance. We provided lists, of possible individuals and possible criteria based on our pilot study and left room for "writein" categories. (See pages 399 to 402 for empirical summaries). Responses varied quite a bit. Our analysis took into account not only how many times each category was mentioned highest but also weighted the scale ( 1 to 5 ) by the proportion of respondents, and accounted as well for the variability in answers. In other words a category ranked higher over another if it had both a better weighted mean score (a lower one since "l" was most important) and if the spread of answers was smaller, i.e., the standard deviation was smaller.

The analysis revealed that the most important individual in setting investment policy for the captive was by far the parent company financial officer, followed by the risk manager and the top officer of the captive (if other than the two above). Least important were the bank, the insurance management company and the unaffiliated investment advisor. While the risk manager appears to be considered as important, his ranking was some $20 \%$ lower than the number one ranking on the ordinal scale of 1 to 5 . Also noticeable is the rather overwhelming agreement about the importance of the parent financial officer. Close to $90 \%$ of all respondents ranked the parent financial officer 1 or 2 and only $8 \%$ as unimportant, 4 and 5 . The risk manager was perceived as "important" only by close to $40 \%$ of respondents while equal proportion of respondents considered the risk manager as unimportant and the rest $20 \%$ ranked his/her importance as a mild " 3 ". However, risk managers were considered second most influential in setting investment policy and more influential than other officers of the captive or officers of the parent, and clearly more influential than any of the outsiders.

It appeared from the ranking analysis that respondents, by and large, assigned more influence to internal personnel rather than to external ones as far as setting investment policy was concerned. We attempted to test this hypothesis for further statistical significance. Certain scaling techniques and particularly Factor Analysis were used in the attempt to reduce the variety of categories into fewer major factors, namely fewer least correlated factors that might be taken as source variables accounting for the observed interrelations in the data. The analysis yielded two key factors/components which we connoted as "insiders" and "outsiders" in terms of their relationship to the parent company or the captive. Graph 3 positions those individuals within these two label categories and in relation to each other. The depiction presents their relative ranking on the ordinal scale of 1 to 5 .

An analysis of the relationships between captive structural, operational and financial characteristics and the influence various individuals or groups had in setting the investment policy further ascertained the importance of "insiders" as a group versus the "outsiders"," except for group captives and large captives specializing in liability coverages that attached more importance to outsiders, particularly to unaffiliated advisors or professional insurance managers. It seems apparent, therefore, that most captives prefer, by and large, inhouse 
Graph 3

Investment policy inputs

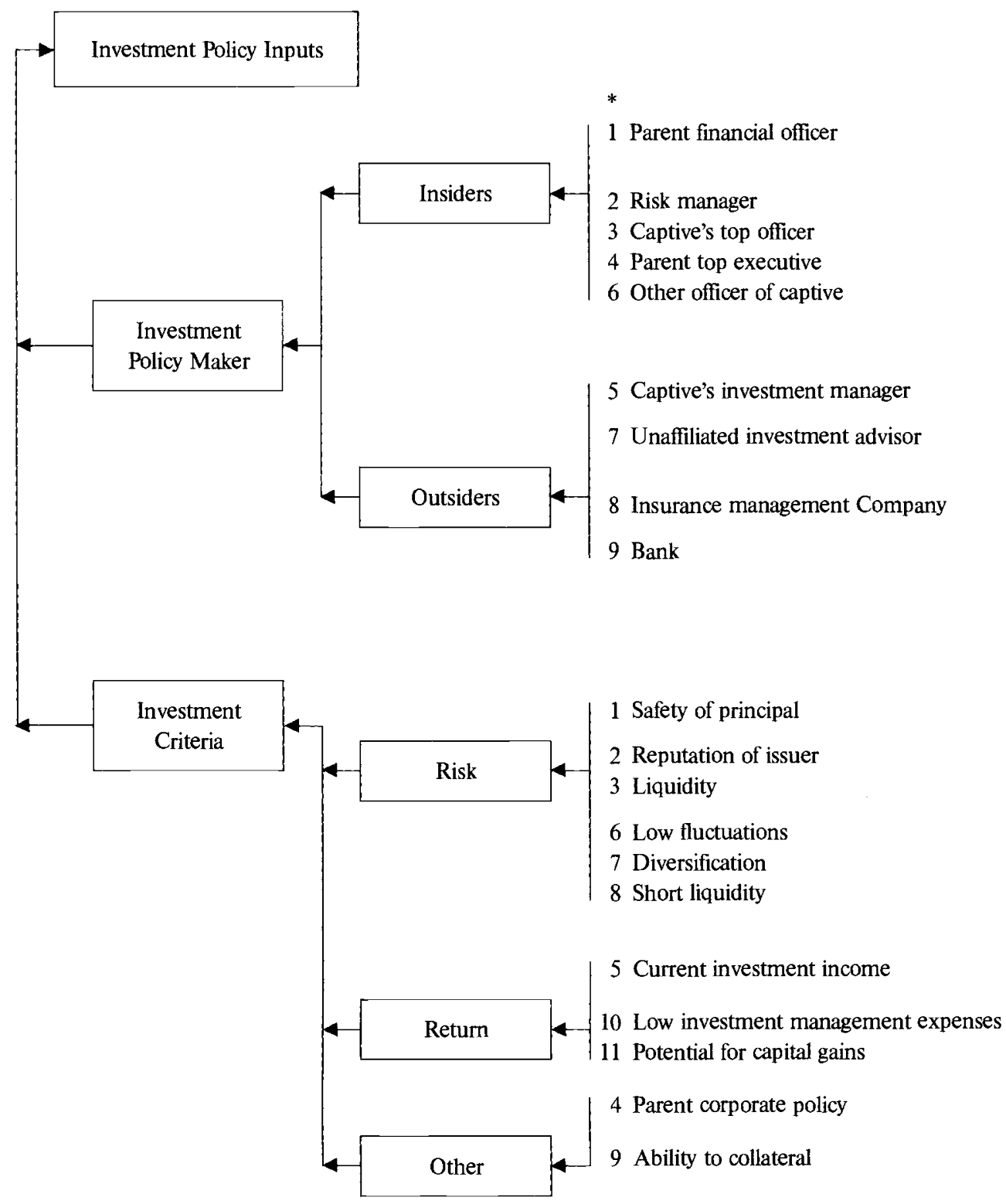

* Ranking based on mean-variance 
personnel. They clearly dominate the setting of investment policy for captive insurers. Only group captives where consensus decision making is common, and very large captives who look for longer investment horizons, tend to value the advice of outside expertise.

Investment criteria is the other variable of investment policy. Here the respondents ranked, on the same scale of 1 to 5, the relative importance of each criterion drawn from a list of 13 pre-selected criterion categories and an optional "write-in" category. Initial analysis ranked all criteria based on similar scaling techniques as described above, namely the mean-variance criterion. ${ }^{10}$ The most important criterion with highest and most concentrated responses was "safety of principal". More than $93 \%$ of all respondents ranked it as number 1 or 2 and only $2 \%$ ranked it as unimportant. "Reputation of the issuer" of the instrument and "liquidity" (within one year) ran second and third with $13 \%$ and $18 \%$ relative lower scores respectively. The least important criterion were "potential for capital gains" and "low management expenses". These ranking results are consistent with the overall conservative investment posture we have identified so far.

Factor analysis to identify principal components among the variety of criteria variables revealed the likehood of two (or three) independent factors where the variety of criteria tended to cluster around. An indepth look reveals that one cluster relates to criteria reflecting investment "risk" issues and the other investment "return" issues. Two additional criteria categories which showed independence in statistical terms from the rest were connoted "other" for lack of a better term. One related to an investment criteria that called for strong consideration of "parent corporate investment policy" and the other which got rather low rating was "the ability to collateralize a letter of credit" as a criterion where or in what instrument to invest. Further testing has shown that "risk" issues as a group where significantly more important than "return" issues, which has been in accordance with the trend of earlier findings. Also, group captives tended to value risk issues particularly liquidity and safety of principal more often than single captives. Lower expenses were significantly more of a concern to group captives rather than to singly owned captives. These results are in accordance with earlier finding indicating that the group captives are more conservative and less investment sophisticated as compared to singly owned captives. The relatively young age of most group captives and the need for consensus management among its members explain these variations.

\subsection{Investment management inputs}

Investment strategy outputs depend not only on policy inputs but also on management inputs. In management inputs we consider the issues of who actually manages the portfolio, who selects the manager and what are the criteria for selection of a manager.

We tabulated the responses to the question who actually executes the day to day investment operations (Table 4). One thing became pretty clear - it has not been the domain of the risk manager. In fact the least likely person to manage the investment portfolio is the risk manager. The individual most likely to manage the portfolio is the parent financial officer, the unaffiliated investment manager or the insurance management company, in that order. 
Graph 4

Investment management inputs

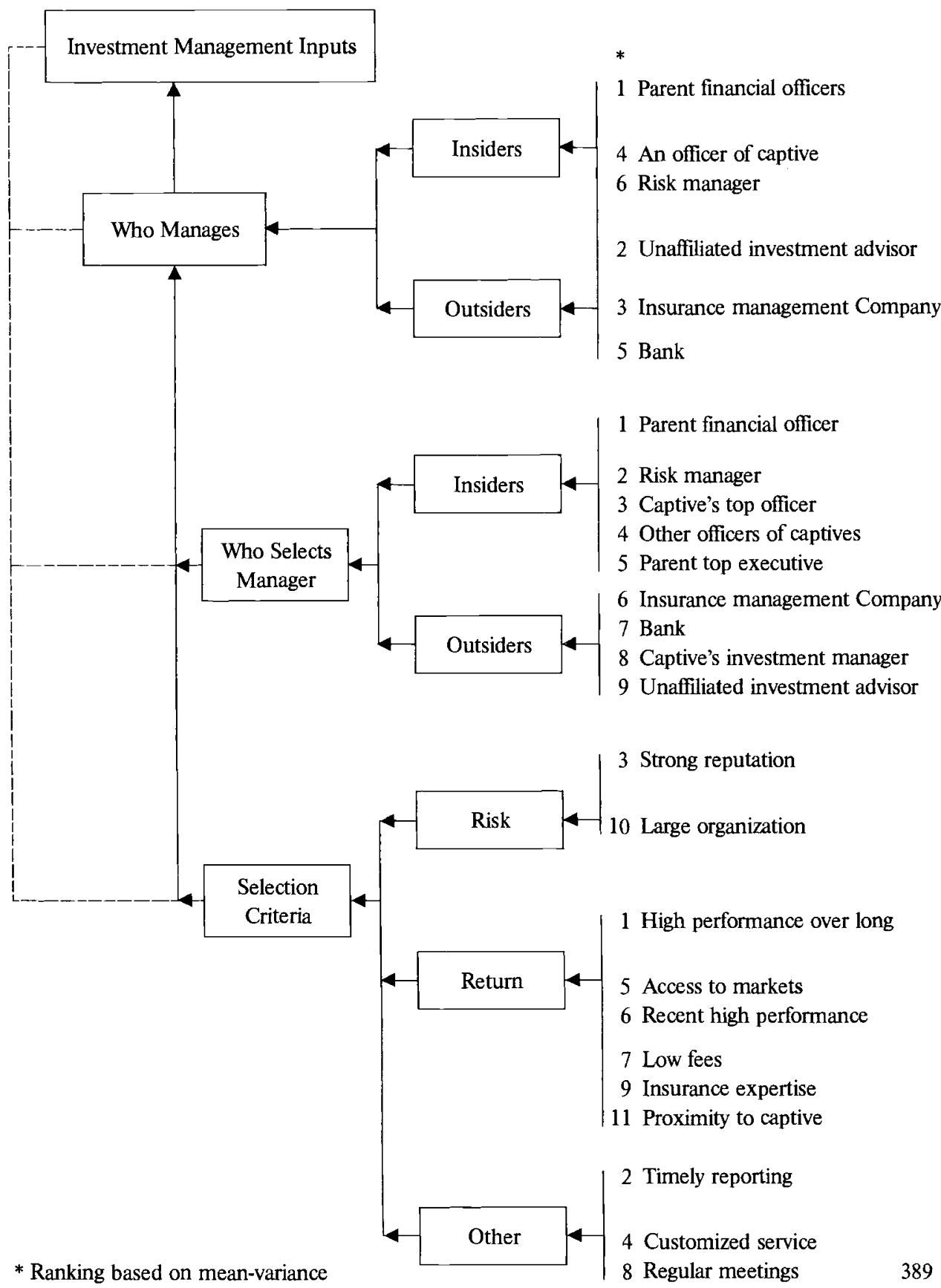


There was a statistically significant division between "insiders" and "outsiders". Insiders as a group dominated the management of investments even though older captives, large ones and those writing unrelated business or primarily liability lines were more likely than others to use unaffiliated advisors. Smaller captives, younger ones and pure captives, if were to use outsiders, would more likely use the insurance management company. These findings make sense in view of the fact that larger and more experienced captives or those who write unrelated or generally long tail coverages have more sophisticated investment needs, such that can be supplied mainly by professional unaffiliated advisors. Smaller captives or pure captives whose investment needs are simple can get investment services more inexpensively within the general service provided by the outside insurance management company.

The answer to who manages the portfolio depends in part on who selects the manager. From a relatively large list of options parent financial officer was ranked as the most important individual in the selection of an investment manager. More than $84 \%$ of the respondents ranked the financial officer as most important and only $8 \%$ as unimportant. Again the risk manager was ranked as the second most important individual in the selection process. Still, however, as in the case of "policy setting" earlier some $38 \%$ of the respondents concluded that risk managers are not influential in the selection process of investment managers. As could have been expected outsiders as a group were by far less important in selecting managers than insiders. Among group captives, however, outsiders were more likely to have some input in the selection of managers. It may be explained in view of the fact that group captives may need an outside opinion that will be acceptable to all member owners.

The criteria for selecting investment manager were collapsed with the help of factor analysis into largely three main components connoted again as "risk", "return" and "other". Contrary to the investment policy criteria where risk issues were clearly much more important than return issues, in selecting a manager one issue, grouped here as an issue of return, "high performance over 3-5 years", was paramount.

The criterion "high performance over 3-5 years" was chosen as the most important issues by more than $83 \%$ of the respondents and considered unimportant by less than $9 \%$. The second most important input was "timely reporting" and the third was "strong reputation". Further analysis reveals that high performance over longer period (3-5 years) was more important to larger captives than to others while "timely reporting" or "regular meetings" were equally important to most captives. It may appear therefore that in selecting managers issues of return are generally dominating. However, "high performance over 3-5 years" which was grouped here with return issues as well as "timely reporting" which was grouped as "other" and "strong reputation", all reflect needs of predictibility and control, therefore some degree of risk concern. In fact the category of short term performance ("high performance last year") was ranked quite low. Our conclusion, therefore, is that the three most important issues in selecting criteria still relate to risk, implying the desire for predictability and control which are inverse to unpredictability, in other words relating to risk. Thus we may conclude (despite the statistically arranged groupings) that issues of risk were still, by and large, the most important ones among the selection criteria much for managers, as was the case in the investment policy criteria. 


\section{Conclusions and evaluation}

The objectives of this study were concerned with the investment patterns of the captive movement as well as with the strategy of captives' investment.

The analysis revealed one key factor that appeared consistent in many facets of the study: captives tend to be conservative in their investment practices as compared to other insurers. Previous research has shown that captives, contrary to many critics' opinions, are pretty conservative in their underwriting exposure ratios and quite conventional in their insurance writings and the use of insurance leverage. Such conservatism in underwriting could have afforded more risk taking in the investment area. But, apparently it spilled over to aversion of risk in investments as well. It manifested itself in preference of generally short term instruments and bonds over equities and generally longer maturities.

We have established a concept of an investment strategy which manifested itself in the choice of instruments and maturities. These however were the outputs of more complex inputs of policy and management. Who sets investment policy, who manages investment portfolio and what are the criteria for both investment policy and manager's selection were the principal inputs. Statistical techniques of collapsing multiple variables into fewer major components allowed to reduce the inputs into largely two categories each. Those who set policy or manage portfolios were either "insiders", i.e., inhouse personnel versus "outsiders". The criteria for investment or selection of managers were largely either of a "risk" or "return" nature.

It appears that minimization of "risk" is the paramount concern both in policy setting as well as in selection of managers even though some return issues and other issues are also important. Consistent with such risk averse disposition, insiders were dominating over outsiders in setting investment policy, in selection of managers and in the actual management of investment portfolios. Generally speaking these findings were rather conclusive across most captives although exception were apparent among larger captives, older ones, group captives and captives writing primarily long tail lines. Often these types of captives were more associated with outsiders influencing policy, selection and actual management of captives. Few of these captives were significantly associated with longer term investment instruments and concerned more with return issues rather than with risk issues. Size and age, which are often highly correlated, as well as the writing of unrelated business or specializing in long tail lines explained the deviations from the rule. Namely, larger captives, "broad" captives and "liability" captives, more often than others, would tend to have more sophisticated investment needs and longer investment horizons. They may, therefore, look more often for unaffiliated investment experts and invest in longer maturities, and in instruments having long or indefinite terms.

Risk managers come out in this study as having a growing influence on investment policy and selection of managers. In fact they were second most important insiders in both areas. However, still more than a third of the respondents disagreed with that assertion. We consider the majority opinion as reflecting a possible trend although still in its evolutionary stages. One issue is without doubt: risk manager although influentual in setting policy and in selecting investment managers are least likely to manage the investment portfolio. This function is often entrusted either with parent financial officer or to an unaffiliated advisor or others. 
Noticing the preponderance of conservative and risk averse attitudes of captives in their investment strategy we were tempted to compare the actual investment performance of our sample respondents with other common investment performance yardsticks. We calculated all pretax investment income including realized and unrealized gains and losses as a percentage of the average investable funds, using reported data for the financial year 1985. Graph 5 depicts a histogram of the number of captives and their overall rate of return. The mean was $9.17 \%$ and the median $9.19 \%$. The results' distribution was between a minimum of $4.44 \%$ to a maximum of $20 \%$ with a standard deviation of $2.66 \%$. The yields of more than three quarters of the respondents were less than $11 \%$.

These results are compatible to the overall investment performance of the total $\mathrm{P} / \mathrm{C}$ industry which yielded as a whole close to $9 \%$. However, captives' investment returns show generally an under performance when compared to total rates of returns in 1985 for the S\&P 500 yielding $31.95 \%$; the total U.S. stock market $23.66 \%$; Bonds (average 7 years) $20.6 \%$. Short term instruments in 1985 yielded within the range of captives' performance; floating rate instruments averaged $9.3 \%$; and short term instruments (C.D., T. Bills, etc.) averaged $8.35 \%$.

Graph 5

Captive Performance

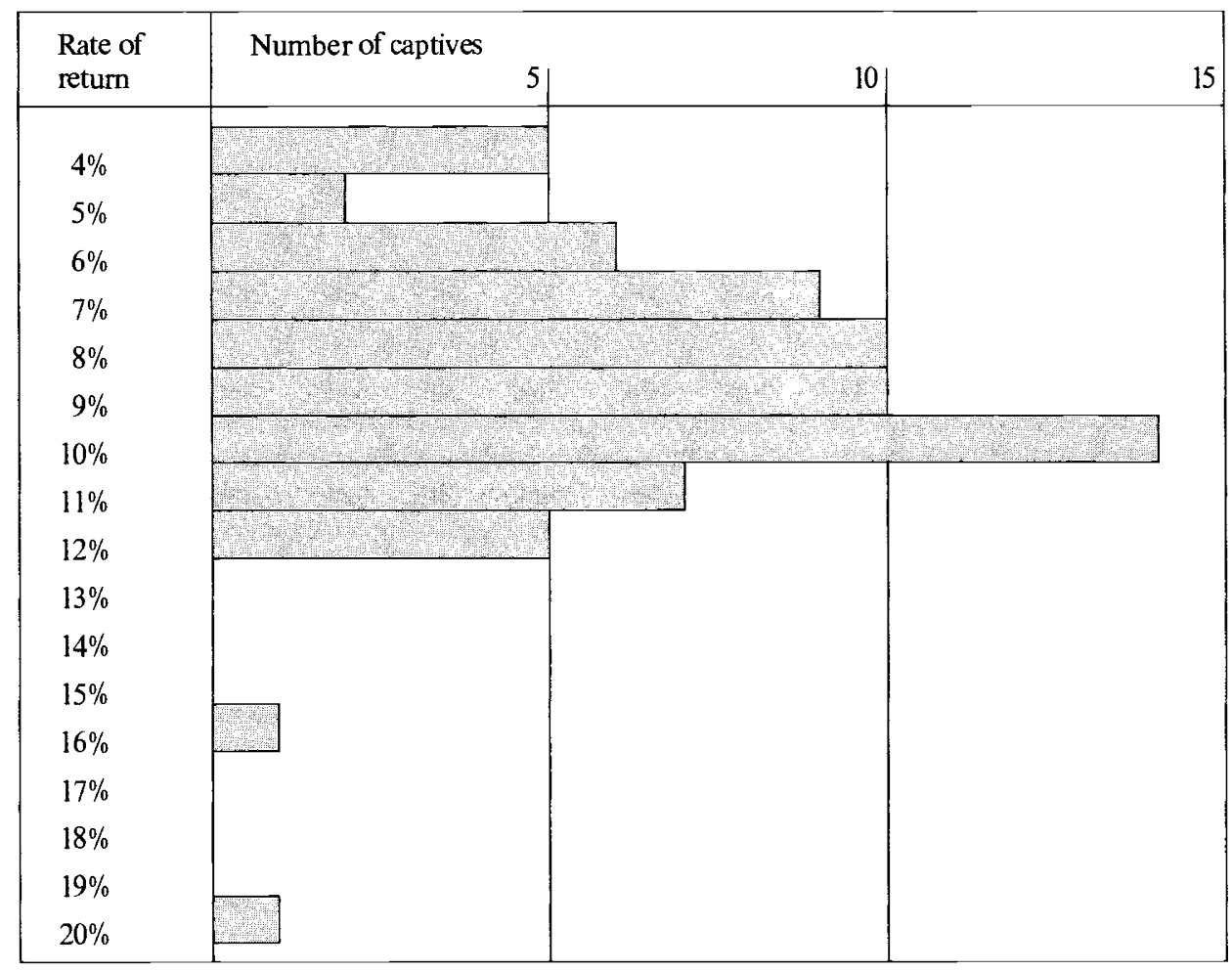




\section{References}

1 M. Moshe Porat, "Captives, Insurance Industry Cycles and the Future", CPCU Journal Vol. 40, No. 1, March 1987 (p. 39-45).

2 See in M. Porat and T. Gasich "The Real Captive Movement in Bermuda", Captive Insurance Company Reports, Sept.-Oct. 1987 (p. 1-4), for a detailed analysis of the distinction between real captives and non-captive offshore insurance entities and other financial aspects of captive insurers.

3 "1986-87 Property Casualty Fact Book" Insurance Information Institute N.Y. 1986 (p. 15). Base on Non-life premiums the captive market would be positioned 7th or 8th on the list of world's leading insurance markets in 1984.

4 M. Porat and T. Rattman, "Captive Investments" Business Insurance Oct. 12, 1987, Perspective - p. 27.

${ }^{5}$ Some of the more prominent examples in this category includes, Walton, Ajax, Gulf's Insco, Murphy Oil's Mentor, etc.

6 Factor analysis is one example of statistical data reduction techniques. Given an array of correlation coefficient set of variables, factor-analytic techniques enable us to see whether some underlying pattern of relationships exists, such that the data may be "rearranged" or "reduced" to a smaller set of factors or components that may be taken as source variables accounting for the observed interrelations in the data. For more details see for example Herman Harry H. "Modern Factor Analysis", Chicago, The University of Chicago Press, 1967.

7 A typical procedure to test for statistical independence would be a Chi-square $\left(\mathrm{x}^{2}\right)$ test, or a T-student paired test. Any statement of statistical association between variables in our reported findings is subject to probability of error of less than $5 \%$. For a more detailed explanation of procedures see for example in Mark L. Berensen and David M. Levine, "Basic Business Statistics - Concepts and Applications", Third ed., Prentice Hall, New Jersey 1986.

8 A regression analysis for ascertaining dependence between instrument mix and maturity mix has shown a degree of statistical correlation of about $76 \%$.

9 To test this we used a technique known as Analysis of Variance in which we test for statistical independence of the categories within versus between the groups. Significance was established with a probability of error of less than $5 \%$. For further details about the technique see for example in Berenson and Levine, Basic Business Statistics, ibid.

10 The mean-variance criterion implies that we ranked the categories according to the lowest mean value but resolved ties based on the smallest standard deviation. A strict application of coefficient of variation ranking would lead here to erronous results. 


\section{Questionnaire \\ Captive insurance investment operations survey}

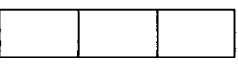

(1) Please indicate the current mix of investment instruments used by your captive. Assign an approximate percentage for each type of instrument in the portfolio.
a. Interest bearing demand account
$\%$
e. Bonds
b. Bank time deposits
f. Equities (e.g. stocks)
c. Floating rate instruments
g. Mutual fund(s)

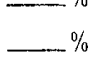
d. Other short term instruments (e.g. comm. paper, T-bills, etc.)
h. Loans to parent/affiliates

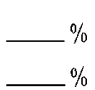

(2) Please indicate the maturity dates of your portfolio's investments as a percent of your total portfolio.
a. One month or less $\%$
d. Six months to one year____ $\%$
g. Five to ten years
_... \%
b. One to three months
e. One year to two years __ $\%$
h. Ten or more years - \%
c. Three to six months
f. Two to five years
i. Indefinite (e.g. stocks) $\%$

(3) Please indicate the mix of currency in your investment portfolio (percentage of total portfolio).
a. U.S. Dollars
d. Swiss Franc
$\%$
g. Canadian Dollar

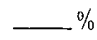
b. Deutsche Mark
e. French Franc
h. Other $\%$
c. Pound Sterling
f. Japanese Yen
i. Other - $\%$

(4) If your investments include other than U.S. dollars, please indicate the reason(s) for such currency mix. If multipurpose, please rank with $1=$ most important.

a. To match ongin of liabilities (loss reserves)

b. Assessment of future currency trends

c. Other (please explain)

(5) Please indicate who executes the day to day investment operations of your captive i.e.; who is the investment manager? (if more than one answer, please rank, $1=$ most important).
a. Parent company financial officers
b. Parent company risk manager
c. An officer of the captive (other than a. or b. above)
d. Bank
e. Insurance management company
f. Unaffiliated (third party) investment advisor
g. Other (please specify)

(6) Various individuals have important inputs into setting an investment policy and selecting the day to day investment manager for the captive. For each individual (a. thru j.) please indicate the importance of their inputs (rate on a scale of 1 to $5 ; 1=$ very important; $5=$ unimportant $/$ no input). 


\begin{tabular}{cc}
\hline $\begin{array}{c}\text { Setting of } \\
\text { general investment } \\
\text { objectives/policy }\end{array}$ & $\begin{array}{c}\text { Selection of } \\
\text { day to day } \\
\text { investment manager }\end{array}$ \\
\hline
\end{tabular}

\section{Individual}

a. Parent's top executive

b. Parent's financial/treasury officers

c. Risk manager of parent

d. Captive's top officer (if other than $a, b, c$ )

e. Other officers of captive (other than a, b, c, d)

f. Insurance management company

g. Captive's investment manager

h. Unaffiliated investment advisor

i. Bank

j. Other (specify)

(7) Please indicate importance of each of the following investment criteria in setting your captive's investment policy (rate on a scale of 1 to $5 ; 1=$ very important; $5=$ unimportant $/$ not considered).
a. Liquidity/matunties over next 30 days
h. Parent's corporate investment policy
b. Liquidity/maturities within a year
i. Low investment management expense
c. Ability to collateralize a letter of credit
j. Reputation of issuer (size, rating, etc.)
d. Potential for capital gains
k. Diversification among issuers
e. High current investment income
1. Diversification among fixed income maturity dates
f. Minimal market value fluctuations
m. Diversification among vehicles/instruments
g. Safety of principal
n. Other (specify)

(8) Please indicate the importance of each of the following criteria in selecting the day to day investment manager Also, please rate your current investment manager against these items (rate on a scale of 1 to $5 ; 1=$ very important; $5=$ unimportant $/$ not considered).

Selection Current

a. High performance over last year

b. High performance over last 3-5 years

c. Belongs to a large organization

d. Strong reputation in the investment industry

e. Substantial knowledge/expertise in insurance industry

f. Low investment management fees charged

g. Presence/access to international markets

h. Ability to individually customize portfolio

* specify the number desired per year;

** specify the number actually occurred 
i. Located in proximity to captive

j. Regular and timely reports

k. Regular meetings with clients

1. Other (specify)

(9) Have you made a change in your investment manager?
a. Never
c. 1-2 years ago
e. Currently considering a change
b. During last year
d. $2+$ years ago

If you have checked (b) through (e), can you indicate the main areas of dissatisfaction by referring to the criteria (a) thru (l) in question 8 .

(10) How did you come in contact with your current investment manager (rank in order of importance if more than one)?
a. Word of mouth

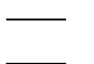
b. Print advertisement
c. Mail brochure
d. Unsolicited visit
e. Recommendation from parent

f. Recommendation from captive management company

g. Recommendation from competitor/peer

h. Recommendation from bank

i. Other (specify)

(11) An alternative to hiring either an inhouse or independent investment manager is to invest in a pooling mechanism such as a mutual fund or a group of mutual funds. Based on your experience and what you know of mutual funds please indicate how well this alternative fulfills each of the following criteria (please rate on a scale of 1 to 5 , $1=$ fulfills very well; 5 = fulfills poorly or not at all):
a. Produces high current income
g. Low investment management fees
b. Potential for capital gains
h. Low transaction costs
c. Safety of principal/manages conservatively
d. Superior performance over last 3-5 years
e. Regular and timely reports
f. Representative meets regularly with clients
i. Ability to individually customize
j. Ability to collateralize letter of credit
k. Provides expertise in specialized areas (e.g. venture capital, foreign stocks, etc.)
1. Other (specify)

(12) For classification purposes only, please indicate approximate figures of the following (please refer to 1985 annual figures, if different please indicate ):

a. Parent company's type of industry classification (or SIC code if known)

b. Is your captive writing unrelated business?

(yes/no)

If yes, what percentage does it represent of your total book of business? $\%$

c. What percent of your captive's book of business is in the following classes?
property
liability
life $\&$ health - $\%$

d. If your captive tends to specializes in only one or a few lines of business, please indicate those lines: 
Table 2

Profile of responses

\begin{tabular}{|c|c|c|c|c|c|c|c|c|c|c|}
\hline \multicolumn{5}{|c|}{ Net Written Premium } & & \multicolumn{5}{|c|}{ Assets } \\
\hline Freq & Pct & $\begin{array}{r}\text { Amount } \\
(000)\end{array}$ & $\begin{array}{r}\text { Mean } \\
(000)\end{array}$ & $\begin{array}{r}\overline{\text { Std Dev }} \\
(000)\end{array}$ & & Freq & Pct & $\begin{array}{r}\text { Amount } \\
(000)\end{array}$ & $\begin{array}{r}\text { Mean } \\
(000)\end{array}$ & $\begin{array}{r}\text { Std Dev } \\
(000)\end{array}$ \\
\hline 3 & 4.9 & 998 & 333 & 245 & $1-\quad 500$ & 1 & 1.6 & 150 & 150 & - \\
\hline 5 & 8.2 & 4,251 & 850 & 194 & $501-1,000$ & 0 & 0.0 & - & - & - \\
\hline 12 & 19.7 & 20,586 & 1,716 & 419 & $1,001-2,500$ & 3 & 4.7 & 5,427 & 1,809 & 417 \\
\hline 11 & 18.0 & 47,0 & 4,278 & 640 & $2,501-5,000$ & 5 & 7.8 & & & 719 \\
\hline 10 & 16.4 & 74,402 & 7,440 & 1,760 & $5,001-10,000$ & 13 & 20.3 & 89 & 6,868 & 1,267 \\
\hline 13 & 21.3 & 196,763 & 15,136 & 4,803 & $10,001-25,000$ & 17 & 26.6 & 273,975 & 16,116 & 4,888 \\
\hline 7 & 11.5 & 234,738 & 33,534 & 6,740 & $25,001-50,000$ & 13 & 20.3 & 435,804 & 33,523 & 6,979 \\
\hline 0 & 0.0 & 0 & 0 & 0 & $50,001-75,000$ & 6 & 9.4 & 385,066 & 64,178 & 7,483 \\
\hline 0 & 0.0 & 0 & 0 & 0 & 75,001-up & 6 & 9.4 & 649,280 & 108,213 & 31,809 \\
\hline 61 & 100.0 & 578,801 & 9,489 & 10,595 & Total & 64 & 100.0 & $1,857,325$ & 29,021 & 32,639 \\
\hline 41 & 67.2 & 147,300 & 3,593 & 2,735 & $1-10,000$ & 22 & 34.4 & 11,320 & 5,145 & 2,483 \\
\hline 20 & 32.8 & 431,501 & 21,575 & 10,487 & 10,001-up & 42 & 65.5 & $1,744,125$ & 41,527 & 34,172 \\
\hline 27 & 65.9 & 316,401 & 11,719 & 11,029 & Pure Captives & 27 & 71.1 & 908,039 & 33,631 & 29,262 \\
\hline 14 & 36.1 & 262,400 & 7,718 & 10,049 & Broad Captives & 11 & 28.9 & 949,286 & 25,656 & 34,904 \\
\hline 51 & 83.6 & 501,624 & 9,836 & 11,154 & Single Owned & 54 & 84.4 & $1,699,852$ & 31,479 & 34,793 \\
\hline 10 & 16.4 & 77,177 & 7,718 & 7,872 & Group Captives & 10 & 15.6 & 157,474 & 15,749 & 9,812 \\
\hline
\end{tabular}

Capital \& Surplus

\begin{tabular}{crrrr}
\hline & & $\begin{array}{r}\text { Amount } \\
(000)\end{array}$ & $\begin{array}{r}\text { Mean } \\
(000)\end{array}$ & $\begin{array}{r}\text { Std Dev } \\
(000)\end{array}$ \\
Freq & Pct & & & \\
2 & 3.0 & 497 & 248 & 167 \\
2 & 3.0 & 1,875 & 938 & 89 \\
14 & 21.2 & 24,899 & 1,779 & 409 \\
12 & 18.2 & 40,921 & 3,410 & 624 \\
14 & 21.2 & 102,989 & 7,356 & 1,674 \\
16 & 24.2 & 270,002 & 16,875 & 4,579 \\
3 & 4.5 & 121,702 & 40,567 & 6,915 \\
3 & 4.5 & 178,000 & 59,333 & 1,155 \\
0 & 0.0 & 0 & 0 & 0 \\
66 & 100.0 & 740,884 & 11,226 & 14,216 \\
44 & 66.7 & 171,180 & 3,890 & 2,729 \\
22 & 33.3 & 569,704 & 25,896 & 16,496 \\
27 & 75.0 & 386,892 & 14,329 & 16,075 \\
9 & 25.0 & 353,992 & 9,077 & 12,543 \\
56 & 84.8 & 699,677 & 12,494 & 15,066 \\
10 & 15.2 & 41,207 & 4,121 & 2,553
\end{tabular}

Investable Funds

\begin{tabular}{crrrr}
\hline & & $\begin{array}{r}\text { Amount } \\
(000)\end{array}$ & $\begin{array}{r}\text { Mean } \\
(000)\end{array}$ & $\begin{array}{r}\text { Std Dev } \\
(000)\end{array}$ \\
Freq & Pct & 625 & 312 & 265 \\
2 & 2.9 & 2,324 & 775 & 162 \\
3 & 4.4 & 2,321 & 1,803 & 320 \\
6 & 8.8 & 10,821 & 835 \\
8 & 11.8 & 32,206 & 4,026 & 8,267 \\
9 & 13.2 & 76,590 & 8,510 & 1,267 \\
21 & 30.9 & 349,894 & 16,662 & 4,902 \\
9 & 13.2 & 325,287 & 36,143 & 7,441 \\
8 & 11.8 & 499,533 & 62,442 & 6,537 \\
2 & 2.9 & 253,012 & 126,506 & 44,556 \\
68 & 100.0 & $1,550,292$ & 22,798 & 27,173 \\
28 & 41.2 & 122,556 & 4,377 & 3,248 \\
40 & 58.8 & $1,427,726$ & 35,693 & 29,104 \\
27 & 81.8 & 708,145 & 27,236 & 26,214 \\
6 & 18.2 & 842,147 & 20,051 & 27,702 \\
58 & 85.3 & $1,428,957$ & 24,637 & 28,950 \\
10 & 14.7 & 121,335 & 12,134 & 6,375
\end{tabular}


Table 3

Profile of responses: Crosstabulation of pure/broad vs. group/single owned captives

Cells contain mean values $(000)$

\begin{tabular}{|c|c|c|c|c|}
\hline & & Pure & Broad & Total \\
\hline \multirow[t]{5}{*}{ Group } & Written & 7,081 & 8,673 & 7,718 \\
\hline & Assets & 12,625 & 20,430 & 15,748 \\
\hline & Cap/Surp & 4,141 & 4,090 & 4,121 \\
\hline & Inv Funds & 11,958 & 12,397 & 12,134 \\
\hline & Frequency & 7 & 4 & 11 \\
\hline \multirow[t]{5}{*}{ Single } & Written & 7,854 & 12,248 & 9,836 \\
\hline & Assets & 28,178 & 35,927 & 31,479 \\
\hline & Cap/Surp & 9,974 & 16,110 & 12,494 \\
\hline & Inv Funds & 21,400 & 29,934 & 24,637 \\
\hline & Frequency & 41 & 27 & 68 \\
\hline \multirow[t]{5}{*}{ Total } & Written & 7,718 & 11,719 & 9,489 \\
\hline & Assets & 25,656 & 33,631 & 29,021 \\
\hline & Cap/Surp & 9,077 & 14,329 & 11,226 \\
\hline & Inv Funds & 20,051 & 27,236 & 22,798 \\
\hline & Frequency & 48 & 31 & 79 \\
\hline
\end{tabular}

Table 4

Survey results: Who manages investment portfolio?

Please indicate who executes the day to day investment operations of your captive i.e., who is the manager (if more than one answer, please rank $1=$ most important)?

(79 Responses)

Parent company financial officers Parent company risk manager

An officer of the captive

Bank

Insurance management company

Unaffiliated investment advisor

\begin{tabular}{rrrrrrr} 
& \multicolumn{2}{c}{ Response Percentages } & & \multicolumn{2}{c}{ Weighted } \\
\cline { 2 - 3 } \cline { 7 - 7 } Freq & 1 & 2 & 3 & & Average & Rank \\
29 & 30.0 & 5.1 & 1.3 & & 102.5 & 1 \\
4 & 1.3 & 3.8 & 0.0 & 7.6 & 6 \\
12 & 10.1 & 3.8 & 1.3 & 39.2 & 4 \\
11 & 12.7 & 0.0 & 1.3 & 39.2 & 4 \\
22 & 21.5 & 3.8 & 2.5 & 74.7 & 3 \\
24 & 27.8 & 2.5 & 0.0 & 88.6 & 2
\end{tabular}


Table 5

Survey results: Who sets investment policy?

Various individuals have important inputs into setting an investment policy and selecting the day to day investment manager for the captive. For each individual (a. thru j.) please indicate the importance of their inputs (rate on a scale of 1 to $5: 1=$ very important; $5=$ unimportant/no input).

\section{Setting of general investment objectives/policy}

\begin{tabular}{|c|c|c|c|c|c|c|c|c|c|}
\hline & \multirow[b]{2}{*}{ Freq } & \multicolumn{5}{|c|}{ Response Percentage } & \multicolumn{3}{|c|}{ Weighted Average } \\
\hline & & 1 & 2 & 3 & 4 & 5 & Mean & S.D. & Rank \\
\hline Parent's top executive & $\begin{array}{l}61 \\
(*)\end{array}$ & $\begin{array}{c}21.3 \\
(16.5)\end{array}$ & $\begin{array}{l}11.5 \\
(8.9)\end{array}$ & $\begin{array}{l}11.5 \\
(8.9)\end{array}$ & $\begin{array}{l}11.4 \\
(8.9)\end{array}$ & $\begin{array}{c}44.3 \\
(60.0)\end{array}$ & $\begin{array}{c}2.54 \\
(2.19)\end{array}$ & $\begin{array}{c}1.64 \\
(1.58)\end{array}$ & 4 \\
\hline Parent's financial/treasury officers & $\begin{array}{l}74 \\
\left(^{*}\right)\end{array}$ & $\begin{array}{c}82.4 \\
(77.2)\end{array}$ & $\begin{array}{c}13.5 \\
(12.7)\end{array}$ & $\begin{array}{c}2.7 \\
(2.5)\end{array}$ & $\begin{array}{c}0.0 \\
(0.0)\end{array}$ & $\begin{array}{c}1.4 \\
(7.6)\end{array}$ & $\begin{array}{c}4.76 \\
(4.52)\end{array}$ & $\begin{array}{c}0.63 \\
(1.11)\end{array}$ & \\
\hline Risk manager of parent & $\begin{array}{l}62 \\
\left(^{*}\right)\end{array}$ & $\begin{array}{c}19.4 \\
(15.2)\end{array}$ & $\begin{array}{c}30.6 \\
(24.1)\end{array}$ & $\begin{array}{c}21.0 \\
(16.5)\end{array}$ & $\begin{array}{c}4.8 \\
(3.8)\end{array}$ & $\begin{array}{c}24.2 \\
(40.5)\end{array}$ & $\begin{array}{c}3.16 \\
(2.70)\end{array}$ & $\begin{array}{c}1.45 \\
(1.56)\end{array}$ & \\
\hline Captive's top officer & $\begin{array}{l}41 \\
(*)\end{array}$ & $\begin{array}{c}22.0 \\
(11.4)\end{array}$ & $\begin{array}{l}17.1 \\
(8.9)\end{array}$ & $\begin{array}{c}26.8 \\
(13.9)\end{array}$ & $\begin{array}{c}7.3 \\
(3.8)\end{array}$ & $\begin{array}{c}26.8 \\
(62.0)\end{array}$ & $\begin{array}{c}3.00 \\
(2.04)\end{array}$ & $\begin{array}{c}1.50 \\
(1.47)\end{array}$ & \\
\hline Other officers of captive & $\begin{array}{l}45 \\
\left(^{*}\right)\end{array}$ & $\begin{array}{l}15.6 \\
(8.9)\end{array}$ & $\begin{array}{c}6.7 \\
(3.8)\end{array}$ & $\begin{array}{l}11.1 \\
(6.3)\end{array}$ & $\begin{array}{c}8.9 \\
(5.1)\end{array}$ & $\begin{array}{c}57.8 \\
(75.9)\end{array}$ & $\begin{array}{c}2.13 \\
(1.65)\end{array}$ & $\begin{array}{c}1.55 \\
(1.29)\end{array}$ & \\
\hline Insurance management company & $\begin{array}{l}55 \\
\left(^{*}\right)\end{array}$ & $\begin{array}{c}1.8 \\
(1.3)\end{array}$ & $\begin{array}{c}9.1 \\
(6.3)\end{array}$ & $\begin{array}{c}7.3 \\
(5.1)\end{array}$ & $\begin{array}{c}5.5 \\
(3.8)\end{array}$ & $\begin{array}{c}76.4 \\
(83.5)\end{array}$ & $\begin{array}{c}1.55 \\
(1.38)\end{array}$ & $\begin{array}{c}1.09 \\
(0.94)\end{array}$ & \\
\hline Captive's investment manager & $\begin{array}{l}46 \\
(*)\end{array}$ & $\begin{array}{c}6.5 \\
(3.8)\end{array}$ & $\begin{array}{l}13.0 \\
(7.6)\end{array}$ & $\begin{array}{c}19.6 \\
(11.4)\end{array}$ & $\begin{array}{c}8.7 \\
(5.1)\end{array}$ & $\begin{array}{c}52.2 \\
(72.2)\end{array}$ & $\begin{array}{c}2.13 \\
(1.66)\end{array}$ & $\begin{array}{c}1.36 \\
(1.18)\end{array}$ & \\
\hline Unaffiliated investment advisor & $\begin{array}{l}53 \\
\left(^{*}\right)\end{array}$ & $\begin{array}{c}7.5 \\
(5.1)\end{array}$ & $\begin{array}{c}7.5 \\
(5.1)\end{array}$ & $\begin{array}{c}5.7 \\
(3.8)\end{array}$ & $\begin{array}{l}11.3 \\
(7.6)\end{array}$ & $\begin{array}{c}67.9 \\
(78.5)\end{array}$ & $\begin{array}{c}1.75 \\
(1.51)\end{array}$ & $\begin{array}{c}1.30 \\
(1.12)\end{array}$ & \\
\hline Bank & $\begin{array}{l}51 \\
\left({ }^{*}\right)\end{array}$ & $\begin{array}{c}2.0 \\
(1.3)\end{array}$ & $\begin{array}{c}2.0 \\
(1.3)\end{array}$ & $\begin{array}{c}3.9 \\
(2.5)\end{array}$ & $\begin{array}{c}5.9 \\
(3.8)\end{array}$ & $\begin{array}{c}86.3 \\
(91.1)\end{array}$ & $\begin{array}{c}1.28 \\
(1.17)\end{array}$ & $\begin{array}{c}0.80 \\
(0.66)\end{array}$ & \\
\hline Other & $\begin{array}{l}17 \\
(*)\end{array}$ & $\begin{array}{l}11.8 \\
(2.5)\end{array}$ & $\begin{array}{c}5.9 \\
(1.3)\end{array}$ & $\begin{array}{c}0.0 \\
(0.0)\end{array}$ & $\begin{array}{c}0.0 \\
(0.0)\end{array}$ & $\begin{array}{c}82.4 \\
(96.2)\end{array}$ & $\begin{array}{c}1.65 \\
(1.14)\end{array}$ & $\begin{array}{c}1.46 \\
(0.71)\end{array}$ & \\
\hline
\end{tabular}

$\left(^{*}\right)$ Assuming that no answer represent a " 5 " (unimportant/no input). 
Table 6

\section{Survey results: Who selects manager?}

Various individuals have important inputs into setting an investment policy and selecting the day to day investment manager for the captive. For each individual (a. thru j.) please indicate the importance of their inputs (rate on a scale of 1 to $5: 1=$ very important; $5=$ unimportant/no input).

\section{Selection of day to day investment manager}

\begin{tabular}{|c|c|c|c|c|c|c|c|c|c|}
\hline & \multirow[b]{2}{*}{ Freq } & \multicolumn{5}{|c|}{ Response Percentage } & \multicolumn{3}{|c|}{ Weighted Average } \\
\hline & & 1 & 2 & 3 & 4 & 5 & Mean & S.D. & Rank \\
\hline Parent's top executive & $\begin{array}{r}50 \\
\left(^{*}\right)\end{array}$ & $\begin{array}{l}14.0 \\
(8.9)\end{array}$ & $\begin{array}{c}8.0 \\
(5.1)\end{array}$ & $\begin{array}{c}6.0 \\
(3.8)\end{array}$ & $\begin{array}{c}8.0 \\
(5.1)\end{array}$ & $\begin{array}{c}64.0 \\
(77: 2)\end{array}$ & $\begin{array}{c}2.00 \\
(1.63)\end{array}$ & $\begin{array}{c}1.53 \\
(1.30)\end{array}$ & 5 \\
\hline Parent's financial/treasury officers & $\begin{array}{l}62 \\
\left({ }^{*}\right)\end{array}$ & $\begin{array}{c}74.2 \\
(78.5)\end{array}$ & $\begin{array}{c}9.7 \\
(58.2)\end{array}$ & $\begin{array}{c}6.5 \\
(5.1)\end{array}$ & $\begin{array}{c}1.6 \\
(12.7)\end{array}$ & $\begin{array}{c}8.1 \\
(27.8)\end{array}$ & $\begin{array}{c}4.40 \\
(3.67)\end{array}$ & $\begin{array}{c}1.21 \\
(1.77)\end{array}$ & 1 \\
\hline Risk manager of parent & $\begin{array}{l}52 \\
\left({ }^{*}\right)\end{array}$ & $\begin{array}{c}23.1 \\
(15.2)\end{array}$ & $\begin{array}{c}25.0 \\
(16.5)\end{array}$ & $\begin{array}{l}13.5 \\
(8.9)\end{array}$ & $\begin{array}{c}1.9 \\
(1.3)\end{array}$ & $\begin{array}{c}36.5 \\
(58.2)\end{array}$ & $\begin{array}{c}2.96 \\
(2.29)\end{array}$ & $\begin{array}{c}1.64 \\
(1.63)\end{array}$ & 2 \\
\hline Captive's top officer & $\begin{array}{l}37 \\
\left(^{*}\right)\end{array}$ & $\begin{array}{c}27.0 \\
(12.7)\end{array}$ & $\begin{array}{l}13.5 \\
(6.3)\end{array}$ & $\begin{array}{l}13.5 \\
(6.3)\end{array}$ & $\begin{array}{c}8.1 \\
(3.8)\end{array}$ & $\begin{array}{c}37.8 \\
(70.9)\end{array}$ & $\begin{array}{c}2.84 \\
(1.86)\end{array}$ & $\begin{array}{c}1.69 \\
(1.47)\end{array}$ & 3 \\
\hline Other officers of captive & $\begin{array}{l}40 \\
\left({ }^{*}\right)\end{array}$ & $\begin{array}{c}20.0 \\
(10.1)\end{array}$ & $\begin{array}{l}10.0 \\
(5.1)\end{array}$ & $\begin{array}{c}7.5 \\
(3.8)\end{array}$ & $\begin{array}{c}5.0 \\
(2.5)\end{array}$ & $\begin{array}{c}57.5 \\
(78.5)\end{array}$ & $\begin{array}{c}2.30 \\
(1.66)\end{array}$ & $\begin{array}{c}1.68 \\
(1.36)\end{array}$ & 4 \\
\hline Insurance management company & $\begin{array}{l}49 \\
(*)\end{array}$ & $\begin{array}{l}10.2 \\
(6.3)\end{array}$ & $\begin{array}{c}8.2 \\
(5.1)\end{array}$ & $\begin{array}{c}6.1 \\
(3.8)\end{array}$ & $\begin{array}{c}4.1 \\
(2.5)\end{array}$ & $\begin{array}{c}71.4 \\
(82.3)\end{array}$ & $\begin{array}{c}1.82 \\
(1.51)\end{array}$ & $\begin{array}{c}1.42 \\
(1.19)\end{array}$ & 6 \\
\hline Captive's investment manager & $\begin{array}{l}41 \\
(*)\end{array}$ & $\begin{array}{c}4.9 \\
(2.5)\end{array}$ & $\begin{array}{c}4.9 \\
(2.5)\end{array}$ & $\begin{array}{c}4.9 \\
(2.5)\end{array}$ & $\begin{array}{c}2.4 \\
(1.3)\end{array}$ & $\begin{array}{c}82.9 \\
(91.1)\end{array}$ & $\begin{array}{c}1.46 \\
(1.24)\end{array}$ & $\begin{array}{c}1.12 \\
(0.84)\end{array}$ & 8 \\
\hline Unaffiliated investment advisor & $\begin{array}{l}42 \\
(*)\end{array}$ & $\begin{array}{c}7.1 \\
(3.8)\end{array}$ & $\begin{array}{c}2.4 \\
(1.3)\end{array}$ & $\begin{array}{c}0.0 \\
(0.0)\end{array}$ & $\begin{array}{c}7.1 \\
(3.8)\end{array}$ & $\begin{array}{c}83.3 \\
(91.1)\end{array}$ & $\begin{array}{c}1.43 \\
(1.23)\end{array}$ & $\begin{array}{c}1.13 \\
(0.85)\end{array}$ & 8 \\
\hline Bank & $\begin{array}{r}14 \\
\left({ }^{*}\right)\end{array}$ & $\begin{array}{l}14.3 \\
(2.5)\end{array}$ & $\begin{array}{c}0.0 \\
(0.0)\end{array}$ & $\begin{array}{c}0.0 \\
(0.0)\end{array}$ & $\begin{array}{c}0.0 \\
(0.0)\end{array}$ & $\begin{array}{c}85.7 \\
(91.1)\end{array}$ & $\begin{array}{c}1.57 \\
(1.10)\end{array}$ & $\begin{array}{c}1.45 \\
(0.63)\end{array}$ & 7 \\
\hline
\end{tabular}

$\left(^{*}\right)$ Assuming that no answer represent a "5" (unimportant/no input). 
Table 7

\section{Survey results: Investment policy criteria}

Please indicate importance of each of the following investment criteria in setting your captive's investment policy (rate on a scale of 1 to $5: 1=$ very important; $5=$ unimportant $/$ not considered).

\begin{tabular}{|c|c|c|c|c|c|c|c|c|c|}
\hline & \multirow[b]{2}{*}{ Freq } & \multicolumn{5}{|c|}{ Response Percentage } & \multicolumn{3}{|c|}{ Weighted Average } \\
\hline & & 1 & 2 & 3 & 4 & 5 & Mean & S.D. & Rank \\
\hline Liquidity/maturities over next 30 days & $\begin{array}{l}72 \\
(*)\end{array}$ & $\begin{array}{c}29.2 \\
(26.6)\end{array}$ & $\begin{array}{c}18.0 \\
(16.5)\end{array}$ & $\begin{array}{c}29.2 \\
(26.6)\end{array}$ & $\begin{array}{c}5.8 \\
(5.1)\end{array}$ & $\begin{array}{c}18.0 \\
(25.3)\end{array}$ & $\begin{array}{c}3.35 \\
(3.14)\end{array}$ & $\begin{array}{c}1.43 \\
(1.52)\end{array}$ & \\
\hline Liquidity/maturities within a year & $\begin{array}{l}74 \\
(*)\end{array}$ & $\begin{array}{c}45.9 \\
(43.0)\end{array}$ & $\begin{array}{c}20.3 \\
(19.0)\end{array}$ & $\begin{array}{c}17.6 \\
(16.5)\end{array}$ & $\begin{array}{c}8.1 \\
(7.6)\end{array}$ & $\begin{array}{c}8.1 \\
(7.6)\end{array}$ & $\begin{array}{c}3.88 \\
(3.70)\end{array}$ & $\begin{array}{c}1.30 \\
(1.44)\end{array}$ & \\
\hline Ability to coll. letter of credit & $\begin{array}{l}50 \\
(*)\end{array}$ & $\begin{array}{c}42.0 \\
(26.6)\end{array}$ & $\begin{array}{c}16.0 \\
(10.1)\end{array}$ & $\begin{array}{l}10.0 \\
(6.3)\end{array}$ & $\begin{array}{c}20.0 \\
(12.7)\end{array}$ & $\begin{array}{c}50.0 \\
(31.6)\end{array}$ & $\begin{array}{c}2.84 \\
(2.62)\end{array}$ & $\begin{array}{c}1.72 \\
(1.72)\end{array}$ & 10 \\
\hline Potential for capital gains & $\begin{array}{l}57 \\
(*)\end{array}$ & $\begin{array}{c}7.0 \\
(5.0)\end{array}$ & $\begin{array}{c}22.8 \\
(16.5)\end{array}$ & $\begin{array}{c}26.3 \\
(19.0)\end{array}$ & $\begin{array}{c}21.0 \\
(15.2)\end{array}$ & $\begin{array}{c}40.4 \\
(56.9)\end{array}$ & $\begin{array}{c}2.45 \\
(2.23)\end{array}$ & $\begin{array}{c}7.31 \\
(1.31)\end{array}$ & 13 \\
\hline High current investment income & $\begin{array}{l}70 \\
(*)\end{array}$ & $\begin{array}{c}31.4 \\
(27.8)\end{array}$ & $\begin{array}{c}3.0 \\
(26.5)\end{array}$ & $\begin{array}{c}18.6 \\
(16.5)\end{array}$ & $\begin{array}{c}11.4 \\
(10.1)\end{array}$ & $\begin{array}{c}8.6 \\
(19.0)\end{array}$ & $\begin{array}{c}3.64 \\
(3.34)\end{array}$ & $\begin{array}{c}1.27 \\
(1.47)\end{array}$ & \\
\hline Minimal market value fluctuations & $\begin{array}{l}69 \\
(*)\end{array}$ & $\begin{array}{c}26.1 \\
(22.8)\end{array}$ & $\begin{array}{c}33.3 \\
(29.1)\end{array}$ & $\begin{array}{c}23.2 \\
(20.3)\end{array}$ & $\begin{array}{c}8.7 \\
(7.6)\end{array}$ & $\begin{array}{c}8.7 \\
(7.6)\end{array}$ & $\begin{array}{c}3.59 \\
(3.27)\end{array}$ & $\begin{array}{c}1.22 \\
(1.43)\end{array}$ & \\
\hline Safety of principal & $\begin{array}{l}74 \\
(*)\end{array}$ & $\begin{array}{c}83.8 \\
(78.5)\end{array}$ & $\begin{array}{c}9.5 \\
(8.9)\end{array}$ & $\begin{array}{c}2.7 \\
(2.5)\end{array}$ & $\begin{array}{c}1.4 \\
(1.3)\end{array}$ & $\begin{array}{c}1.4 \\
(1.3)\end{array}$ & $\begin{array}{c}4.76 \\
(4.47)\end{array}$ & $\begin{array}{c}0.70 \\
(1.21)\end{array}$ & \\
\hline Parent's corporate investment policy & $\begin{array}{l}70 \\
(*)\end{array}$ & $\begin{array}{c}42.9 \\
(38.0)\end{array}$ & $\begin{array}{c}25.7 \\
(22.8)\end{array}$ & $\begin{array}{c}8.6 \\
(7.6)\end{array}$ & $\begin{array}{c}7.1 \\
(6.3)\end{array}$ & $\begin{array}{c}15.7 \\
(25.3)\end{array}$ & $\begin{array}{c}3.73 \\
(3.42)\end{array}$ & $\begin{array}{c}1.47 \\
(1.64)\end{array}$ & \\
\hline Low investment management expense & $\begin{array}{l}71 \\
(*)\end{array}$ & $\begin{array}{c}8.5 \\
(7.6)\end{array}$ & $\begin{array}{c}21.1 \\
(19.0)\end{array}$ & $\begin{array}{c}33.8 \\
(30.4)\end{array}$ & $\begin{array}{c}14.1 \\
(12.7)\end{array}$ & $\begin{array}{c}22.5 \\
(30.4)\end{array}$ & $\begin{array}{c}2.79 \\
(2.61)\end{array}$ & $\begin{array}{c}1.25 \\
(1.30)\end{array}$ & 11 \\
\hline Reputation of issuer (size, etc.) & $\begin{array}{l}71 \\
(*)\end{array}$ & $\begin{array}{c}52.1 \\
(46.8)\end{array}$ & $\begin{array}{c}31.0 \\
(27.8)\end{array}$ & $\begin{array}{c}5.6 \\
(5.1)\end{array}$ & $\begin{array}{c}2.8 \\
(2.5)\end{array}$ & $\begin{array}{c}8.5 \\
(17.7)\end{array}$ & $\begin{array}{c}4.15 \\
(3.84)\end{array}$ & $\begin{array}{c}1.20 \\
(1.49)\end{array}$ & \\
\hline Divers. among fixed maturity dates & $\begin{array}{l}69 \\
\left(^{*}\right)\end{array}$ & $\begin{array}{c}14.5 \\
(12.7)\end{array}$ & $\begin{array}{c}31.9 \\
(27.8)\end{array}$ & $\begin{array}{c}30.4 \\
(26.6)\end{array}$ & $\begin{array}{c}5.8 \\
(5.1)\end{array}$ & $\begin{array}{c}17.4 \\
(27.8)\end{array}$ & $\begin{array}{c}3.20 \\
(2.92)\end{array}$ & $\begin{array}{c}1.28 \\
(1.40)\end{array}$ & \\
\hline Diversification among issuers & $\begin{array}{l}70 \\
(*)\end{array}$ & $\begin{array}{c}20.0 \\
(17.7)\end{array}$ & $\begin{array}{c}37.1 \\
(32.9)\end{array}$ & $\begin{array}{c}27.1 \\
(24.1)\end{array}$ & $\begin{array}{c}5.7 \\
(5.1)\end{array}$ & $\begin{array}{c}10.0 \\
(20.3)\end{array}$ & $\begin{array}{c}3.51 \\
(3.27)\end{array}$ & $\begin{array}{c}1.18 \\
(1.37)\end{array}$ & \\
\hline Divers. among vehicles/instruments & $\begin{array}{l}69 \\
(*)\end{array}$ & $\begin{array}{c}1.4 \\
(1.3)\end{array}$ & $\begin{array}{c}26.1 \\
(22.8)\end{array}$ & $\begin{array}{c}27.5 \\
(24.1)\end{array}$ & $\begin{array}{c}26.1 \\
(22.8)\end{array}$ & $\begin{array}{c}18.8 \\
(29.1)\end{array}$ & $\begin{array}{c}2.65 \\
(2.44)\end{array}$ & $\begin{array}{c}1.11 \\
(1.17)\end{array}$ & 12 \\
\hline
\end{tabular}

$\left({ }^{*}\right)$ Assuming that no answer represent a " 5 " (unimportant/not considered). 
Table 8

\section{Survey results: Manager selecting criteria}

Please indicate the importance of each of the following criteria in selecting the day to day investment manager. Also, please rate your current investment manager against these items (rate on a scale of 1 to 5 : $1=$ very important; $5=$ unimportant $/$ not considered).

\section{Selection of investment manager}

\begin{tabular}{|c|c|c|c|c|c|c|c|c|c|}
\hline & \multirow[b]{2}{*}{ Freq } & \multicolumn{5}{|c|}{ Response Percentage } & \multicolumn{3}{|c|}{ Weighted Average } \\
\hline & & 1 & 2 & 3 & 4 & 5 & Mean & S.D. & Rank \\
\hline High performance over last year & 46 & 17.4 & 39.1 & 23.9 & 13.0 & 6.5 & 3.48 & 1.73 & 6 \\
\hline High performance over last 3-5 years & 47 & 55.3 & 27.7 & 6.4 & 2.1 & 8.5 & 4.19 & 1.21 & 1 \\
\hline Belongs to a large organization & 47 & 12.8 & 21.3 & 29.8 & 10.6 & 25.5 & 2.85 & 1.37 & 10 \\
\hline Strong reputation & 47 & 34.0 & 36.2 & 12.8 & 6.4 & 10.6 & 3.73 & 1.29 & 2 \\
\hline Substantial expertise in insurance & 46 & 23.9 & 19.6 & 17.0 & 19.6 & 19.6 & 3.09 & 1.47 & 9 \\
\hline $\begin{array}{l}\text { Low investment management fees } \\
\text { charged }\end{array}$ & 47 & 6.4 & 31.9 & 92.6 & 10.6 & 8.5 & 3.12 & 1.01 & 7 \\
\hline Access to international markets & 46 & 28.3 & 30.4 & 21.7 & 8.7 & 10.9 & 3.57 & 1.29 & 5 \\
\hline Ability to customize portfolio & 47 & 38.3 & 25.5 & 14.9 & 10.6 & 10.6 & 3.20 & 1.37 & 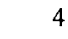 \\
\hline Located in proximity to captive & 46 & 13.0 & 4.3 & 17.4 & 15.2 & 50.0 & 2.15 & 1.43 & 11 \\
\hline $\begin{array}{l}\text { Regular and timely reports } \\
\text { (number desired per year) }\end{array}$ & $\begin{array}{c}48 \\
(42)\end{array}$ & 35.4 & 39.6 & 12.5 & 8.3 & 4.2 & $\begin{array}{c}3.94 \\
(9.95)\end{array}$ & $\begin{array}{c}1.10 \\
(7.81)\end{array}$ & 2 \\
\hline $\begin{array}{l}\text { Regular meetings with clients } \\
\text { (number desired per year) }\end{array}$ & $\begin{array}{c}46 \\
(33)\end{array}$ & 15.2 & 30.4 & 26.1 & 13.0 & 15.2 & $\begin{array}{c}3.17 \\
(5.24)\end{array}$ & $\begin{array}{c}1.29 \\
(9.31)\end{array}$ & \\
\hline
\end{tabular}

